\title{
Positive impacts among the negative impacts of the COVID-19 pandemic for community life
}

\author{
Aam Amirudin ${ }^{1}$, M. Syamsul ${ }^{1}$, Christin Sri Marnani ${ }^{1}$, Nadiva Awalia Rahmah $^{1}$, and Wilopo ${ }^{1}$ \\ ${ }^{1}$ Disaster Management Study Program, National Security Faculty, Republic of Indonesia Defense University. IPSC Sentul Area, \\ Bogor, West Java, Indonesia
}

\begin{abstract}
The Covid-19 pandemic is a global disease outbreak that quickly spreads throughout the world and transmits from one person to another so easily and is a form of danger that has the potential to threaten all aspects of people's lives. These negative impacts include social, economic, health, and psychological impacts, even to the point of threatening national defense and security, due to the limited space for human movement in carrying out daily activities. But there are also positive influences that we unconsciously admit, not only producing clean air but making individuals mentally strong and changing personalities for a better life. Adaptation of new life patterns from before makes people learn about the meaning of maintaining cleanliness in the face of a pandemic with new habits in maintaining personal hygiene, family, and the surrounding environment. The long-term impact on society is to produce people who are tough in facing life by taking advantage of existing opportunities into innovations in running life with the emergence of creative businesses as a new source of income in meeting the needs of families today and in the future.
\end{abstract}

\section{Introduction}

The Covid-19 pandemic has greatly affected most of the world's people's lives, all aspects of life such as aspects of ideology, politics, economy, social, culture, defense, and national security with the Covid-19 pandemic. All of this happened because the spread of Covid-19 was very fast and massive, so the transmission rate was so large with a very worrying effect. as evidenced by the positive confirmation numbers and large mortality rates in each affected country, both developed countries, developing countries, especially poor countries with low levels of knowledge, sanitation, and care, thus adding to the very high vulnerability of the spread of Covid-19.

Countries in the world are so intense in tackling the Covid-19 pandemic, all ways are done so that their people avoid the spread of the Covid-19 pandemic, the methods used are based on pathogenic characteristics, epidemiological characteristics, and clinical characteristics. These three characteristics can be used as a reference to find out if the pandemic is spreading to healthy humans and in the end, it will be known how to deal with it.

Good response efforts will also have a significant impact on people's lives. Good cooperation is needed between all parties, the Government as policymakers and the community as policy implementers will be interrelated to the success of overcoming the Covid-19 Pandemic in a country. Policy Strict health protocols are very popular policies in every country in the world. Wearing masks, keeping a distance by staying away from crowds and contact with sick individuals and washing hands are real efforts that are highly recommended in efforts to overcome the Covid-19 Pandemic [1].

The application of strict health protocols in each country has an impact on the pattern of people's daily lives, efforts to maintain a distance of 1-2 meters between fellow humans lead to restrictions on activities outside the home. This is done to avoid interaction between humans because droplets from the human nose or mouth as a nesting place for Covid-19 are feared to spread to various places, either directly or indirectly, that will reach the surrounding humans [2].

Restrictions on community activities in daily activities lead to a decrease in work productivity, especially in business fields that depend on workers, the impact is that many employees are laid off. Many conventional traders lose out because of the lack of buyers and many other business fields are affected so that the income they usually get is reduced or even non-existent. This causes many in the community to become the new poor [3].

* Corresponding author: aamonusco130519@gmail.com 
The Covid-19 pandemic has also caused community resilience to be high because difficulties become a challenge for people to survive, causing innovations to emerging in all respects, including in creating their business world. Supported by advances in science and technology with the internet which makes it easy for people to access various kinds of information. This is very helpful to get out of the difficult zone in the era of the Covid-19 Pandemic

From the explanation above, the author is interested in raising the theme "Positive impacts among the negative impacts of the Covid-19 Pandemic on people's lives" with the hope that this paper can be a motivation for the wider community that in trouble there is always wisdom and a way to make us at ease.

\section{Methods}

The research method used is a descriptive qualitative approach based on a literature review and analysis of several references. The references used in this study serve as a basis for providing valid information to discuss and draw conclusions on the positive impacts among the negative impacts of the Covid-19 Pandemic on people's lives. This study uses the qualitative data analysis technique of Miles and Huberman (1994), whose process consists of data reduction, data presentation, and conclusion drawing and verification [4]. The data reduction process in this study was carried out by making choices about which parts of the data were coded and discarded. In the data reduction process, qualitative data can be simplified and transformed in various ways, such as through strict selection, through a summary or brief description, through data classification in a broader pattern, and so on. The presentation of data is done by developing a structured set of information that will lead or produce conclusions. This process is also carried out to further improve the understanding of this research and serve as a reference for taking action. By analyzing the data that has been displayed, we will be able to understand what is going on and what to do based on our understanding of the data.

\section{Results and Discussion}

Global Covid-19 Pandemic cases are still showing a significant increase, data shows that there is still a high rate of increase in the number of confirmed patients as of May 17, 2021. According to data from Worldometers, the total number of confirmed cases of Covid-19 worldwide has reached positive numbers. as many as $163,694,333$ cases, 3,392,634 people died and 142,144,554 people were declared recovered. From the data of 10 countries with the highest number of Covid-19 in the world, the USA is the country with the highest number of infection cases, followed by India, Brazil, France, Turkey, Russia, UK, Italy, Spain, and Germany [5].

The Covid-19 pandemic has a very complex impact on every individual life or relationship between individuals. The very fast transmission of the virus requires that efforts be made to limit activities or isolate from the outside world to break the chain of transmission, causing depression, anxiety conditions which are also associated with instability, severe emotional trauma, and economic recession because people cannot carry out production, distribution, and distribution activities. consumption and has a major impact on the structure of society that causes a social change in society [6]. UNCTAD predicts the global economy is expected to contract a staggering $4.3 \%$ in 2020. Millions of jobs have been lost, millions of livelihoods are threatened, and it is estimated that an additional 130 million people will live in extreme poverty if the crisis continues [6].

A Covid-19 pandemic is an unexpected event that comes suddenly beyond the reach or ability of humans. unintended social consequences. The phenomenon of Covid-19 certainly has a very complex impact on every life or relationship between individuals in humans. The psychological and social impact is influenced by people's fear of becoming sick. People's suspicion will lead to an uncertain social situation, people's attitudes become more protective of the surrounding environment, they are more suspicious of people who cough, sneeze, or people who look sick. From this stigma, finally, a discriminatory attitude emerged by not wanting to help other people by direct physical contact with people suspected of contracting the coronavirus [8].

Public suspicion will lead to an uncertain social situation, people's attitudes become more over-protective of their surroundings, they are more suspicious of people who are coughing, sneezing or people who look sick. From this stigma, a discriminatory attitude finally emerged, for example not wanting to help others in direct physical contact with people suspected of having the coronavirus, refusal of a nurse in the neighborhood because the nurse working in a hospital that accepts Covid-19 patients, refusal to bury the bodies of Covid-19 victims. -19 by several residents, even throwing stones at the medical officers who are tasked with carrying the bodies of Covid-19 victims by ambulance.

From an economic aspect, it is closely related to the economic adequacy of the community, which will be achieved if the income can cover their daily needs, with the Covid-19 Pandemic many business sectors are experiencing shocks, according to Small Business Report data by Facebook, OECD, and the World Bank, which surveyed nearly 30,000 businesses in 50 countries, said $61 \%$ of small and medium enterprises (SMEs) in the Asia Pacific had reported a drop in sales due to the Covid-19 pandemic [9].

The industrial, tourism, trade, and other services sectors are also greatly affected because these sectors are one of the forums that provide job opportunities for the community, but due to the Covid-19 pandemic, many people who depend on work in these sectors are missing, the impact is Layoffs (Termination of Employment). Data from the UNWTO showed that tourist arrivals in March fell by $57 \%$ as lockdowns began in many countries, and extensive travel, airport closures, and national borders. This means 67 million international arrivals and around US $\$ 80$ billion in revenue, 100 to 120 million jobs will be at risk [10]. 
In addition, the Covid-19 pandemic has a positive impact on some citizens in the world, many countries in the world impose lockdowns or restrictions on community activities so that all activities ranging from work, school, shopping, to other activities become more at home, it makes us become spending more time with family, people in various circles are also competing to donate to help people in need. This is social solidarity that is unconsciously embedded in society [11].

Besides that, the condition of the earth is getting better due to reduced human activity so that the level of pollution is reduced due to the decrease in fossil fuel consumption by 435,000 barrels globally in the first 3 months of 2020 [12], for example, the PRC can cut 1,600 metric tons of $\mathrm{CO} 2$ or the equivalent of above $4 \%$. of total Global CO2 production in 2019 [13].

The Covid-19 pandemic has affected business growth in various sectors, although some of them have lost money and even gone bankrupt but several successful business opportunities have made big profits. Launching from CNN Business, there are several lists of businesses that thrive in the USA during 2020 and are predicted to grow rapidly in the future, namely: 1) Housing increases 23\%; 2) Energy based on solar power increased by $300 \%$; 3) Bitcoin increases 3x; 4) Video Games increased by 100 billion game content broadcast hours; 5) Large retailers increased by $19 \%$; 6) Technologies like Zoom skyrocketed by $307 \%$; 7) Digital content increased by $134 \%$; 8) Stream like Warner Bros. that thrives with its films [14].

Disruption or drastic changes due to the COVID-19 pandemic has forced the public, business actors, and the government to carry out various digital innovations. These measures are carried out, among others, through distance learning, online public services, the development of online surveys, and telemedicine development [15].

Changes in lifestyle habits due to the Covid-19 Pandemic have caused a shift in the behavior of the world community, due to limited movement, this is an opportunity to create new innovative business fields as according to the Board of Innovation (BoI) there are several changes in human behavior as a result of the Covid-19 Pandemic, namely: 1). Excessive anxiety; 2). Does not believe in cleanliness outside of itself; 3) Limiting traveling; 4). Work from home; 5) escalation of conflict increases; 6). Unemployment is increasing; 7). Accustomed to sending goods; 8). Limited interaction with others; 9). Self-identity is more important than job identity; 10). Consumer Immunity as Priority [16].

From this pattern of behavior change, people use it to become business opportunities, especially online businesses, which have increased greatly during the Covid-19 Pandemic, considering that online business can minimize interactions between humans without leaving their essence to earn income to support daily needs, according to data from the Ministry of Communication and Information. that the number of online shop transactions has increased by $400 \%$ and is predicted to continue to increase as the Covid-19 pandemic has no signs of ending [16]. In addition, thanks to the Covid-19 pandemic the world gave birth to new billionaires, according to data from the Swiss bank, UBS, during the
April to July 2020 period, the wealth of the number of these billionaires increased by the US $\$ 10.2$ trillion or around Rp144,078 trillion, UBS data also shows, the number of billionaires increased from 2,158 in 2017 to 2,189 [17].

\section{Conclusion}

The Covid-19 pandemic has had a major impact on the lives of people around the world in general. This influence certainly leads to a negative influence with various accompanying impacts from various aspects of human life, such as increased mortality rates, increasing unemployment rates, decreasing the number of visits to the tourism sector, and causing an economic recession because people cannot carry out production, distribution, consumption activities such as at normal times.

On the other hand, there is a positive influence with the emergence of new creativity and innovation as an adjustment effort from humans. The Covid-19 pandemic is still developing, forcing people to adapt to the current situation, which can allow us to continue to survive during the Covid-19 pandemic. Various habits that were carried out when conditions were still normal can no longer be carried out because of the fear of the Covid-19 attack. This is felt by some parties with the increasing standard of living by taking advantage of the existing situation by finding new business methods in the form of online businesses and other businesses. Besides that, with the demands of activities at home, it creates a lot of time together with family. In terms of changing behavior towards the environment, Covid-19 forces people to get used to healthy and clean living behaviors, in addition to the environment because of the limited movement of vehicles so that the air quality becomes clean and healthy too. It turns out that we can all learn that disasters make humans survive so that they give birth to resilient people who can solve all problems and get out of these problems to a better life.

\section{References}

1 Öner Özdemir, "Coronavirus Disease 2019 (COVID19): Diagnosis and Management (narrative review)," Erciyes Medical Journal 42, 3, 242-247 (2020)

2 WHO, "Rational use of personal protective equipment (PPE) for coronavirus disease (COVID19)," last modified 2020, diakses Mei 19, 2021, https://apps.who.int/iris/bitstream/handle/10665/331 498/WHO-2019-nCoV-IPCPPE_use-2020.2-eng.pdf (2020)

3 Maryla Maliszewska, "The Potential Impact of COVID-19 on GDP and Trade," Policy Research Working Paper (2020).

4 M. B. Miles, A.M Huberman, Qualitative Data Analysis: An Expanded Sourcebook. New York: Sage (1994).

5 Jawahir Gustav Rizal, "Update Corona Dunia 17 Mei 3,3 Juta Orang Meninggal Dunia karena Covid-19'(World Corona Update May 17, 3.3 
Million People Died due to Covid-19). https://www.kompas.com/tren/read/2021/05/17/093 407265/update-corona-dunia-17-mei-33-juta-orangmeninggal-dunia-karena-covid-19.

6 R. Perween, "Global Impact of COVID-19 Pandemic," International Journal of Natural Disasters \& Health Security, July, 53-64, (2020)

7 UNCTAD, Impact of the COVID-19 pandemic on trade and development: Transitioning to a New Normal., United Nations Conference on Trade and Development (2020)

8 D. Joy Osofsky, J. Howard, Osofsky, Y. L. Mamon, "Psychological and Social Impact of COVID-19," Psychological Trauma: Theory, Research, Practice, and Policy 12, no. 5 (2020): 468-469.

9 Cloudhost, "Dampak Pandemi (COVID-19) Terhadap Bisnis UKM dan Startup," Cloudhost, last modified 2020, diakses Mei 19, 2021, https://idcloudhost.com/dampak-pandemi-covid-19terhadap-bisnis-ukm-dan-startup/.

10 T Haryanto, "Editorial: Covid-19 Pandemic and International Tourism Demand," Journal of Developing Economies 5, no. 1 (2020): 1.

11 K. Dwari, "Covid-19 Pandemic: A Positive Influence on Lifestyle, Economy, Administration \& Environment; An Overview," Indian Journal of Forensic Medicine \& Toxicology 14, no. 4 (2020).

12 IEA, “Oil Market Report - March 2020," IEA, last modified 2020, diakses Mei 19, 2021, https:/www.iea.org/reports/oil-market-reportmarch-2020.

13 Simon Evans, "Analysis: Coronavirus set to cause largest ever annual fall in $\mathrm{CO} 2$ emissions," CarbonBrief, last modified 2020, [Accessed May 19,
2020] https://www.carbonbrief.org/analysiscoronavirus-set-to-cause-largest-ever-annual-fall-inco2-emissions (2020)

14 CNN Indonesia, "Daftar Bisnis Untung dan Buntung di AS Sepanjang 2020," CNN, last mo, https://www.cnnindonesia.com/ekonomi/202101041 14852-92-589177/daftar-bisnis-untung-danbuntung-di-as-sepanjang-2020/1. [Accessed May 19, 2020],

15 Widyati, IDK Kertawidana, " Positive impacts of Covid-19 pandemic to strengthen National Health Defense" Technium Social Sciences Journal 24, 562570, October (2021)

16 Bentangku, "14 Jenis Usaha Ini Diramalkan Naik Daun di tahun 2021,"( This Business is Forecasted to Rise in 2021), Qasir [Accessed May 19, 2020] https://www.qasir.id/inspirasi/14-jenis-usaha-inidiramalkan-naik-daun-di-tahun-2021.

17 Gusti, “Transaksi Penjualan Online Naik 400 Persen di Masa Pandemi Covid-19," UGM, last modified 2020, diakses Mei 19, 2021, https://www.ugm.ac.id/id/berita/19452-transaksipenjualan-online-naik-400-persen-di-masa-pandemicovid-19.

18 BBC, "Kekayaan para miliarder bertambah Rp144.078 triliun selama pandemi Covid-19, Jeff Bezos bertambah Rp1.200 triliun,"( The wealth of billionaires increased by Rp144,078 trillion during the Covid-19 pandemic, Jeff Bezos increased by Rp1,200 trillion) BBC News, https://www.bbc.com/indonesia/majalah-55465990 [Accessed May 19, 2020] 